ORIGINAL ARTICLE, PHARMACY

\title{
Beneficial Effect of Chronic Treatment with Extracts from Rhodiola Rosea L. and Curcuma Longa L. on the Immunoreactivity of Animals Subjected to a Chronic Mild Stress Model
}

\author{
Liliya V. Vasileva ${ }^{1,2}$, Kremena E. Saracheva ${ }^{1,2}$, Mariya V. Ivanovska ${ }^{3,4}$, Atanaska P. Petrova ${ }^{3,4}$, \\ Emir Sucouglu ${ }^{5}$, Mariana A. Murdjeva ${ }^{3,4}$, Damyanka P. Getova-Spasova $^{6}$ \\ ${ }^{1}$ Department of Pharmacology and Clinical Pharmacology, Faculty of Medicine, Medical University of Plovdiv, Plovdiv, Bulgaria \\ ${ }^{2}$ Department of Pharmacology and Drug Toxicology, Faculty of Pharmacy, Medical University of Plovdiv, Plovdiv, Bulgaria \\ ${ }^{3}$ Department of Microbiology and Immunology, Faculty of Pharmacy, Medical University of Plovdiv, Plovdiv, Bulgaria \\ ${ }^{4}$ Division of Immunological Assessment of Post-traumatic Stress Disorder, Technological Center for Emergency Medicine, Plovdiv, \\ Bulgaria \\ ${ }^{5}$ Faculty of Medicine, Medical University of Plovdiv, Plovdiv, Bulgaria \\ ${ }^{6}$ Laboratory of Experimental Neuropharmacology, Technological Center for Emergency Medicine, Plovdiv, Bulgaria
}

\section{Correspondence:}

Liliya V.Vasileva, Department of Pharmacology and Clinical Pharmacology, Faculty of Medicine, Medical University of Plovdiv, Plovdiv, Bulgaria; Department of Pharmacology and Drug Toxicology, Faculty of Pharmacy, Medical University of Plovdiv, 15A Vassil Aprilov Blvd., 4002 Plovdiv, Bulgaria E-mail:vasileva.I.vl@gmail.com Tel: +359 899514113

Received: 23 July 2016 Accepted: 08 March 2017

Published Online: 09 May 2017

Published: 22 Dec 2017

Key words: chronic mild stress, immunoreactivity, LPS-induced inflammation, Rhodiola, Curcuma

Citation: Vasileva LV, Saracheva KE, Ivanovska MV, Petrova AP, Sucouglu E, Murdjeva MA, GetovaSpasova DP. Beneficial effect of chronic treatment with extracts from Rhodiola rosea L. and Curcuma longa $\mathrm{L}$. on the immunoreactivity of animals subjected to a chronic mild stress model.

Folia Medica 2017;59(4):443-53. doi: 10.1515/folmed-2017-0046
Background: Recent studies have suggested increased levels of pro-inflammatory cytokines in depression.

Aim: The present study aimed to evaluate the effect of extracts from Rhodiola and Curcuma on immunoreactivity of animals subjected to a chronic mild stress (CMS) model followed by lipopolysaccharide-induced inflammation.

Materials and methods: Male Wistar rats $(n=56)$ divided in 7 groups were treated orally with: distilled water $10 \mathrm{ml} / \mathrm{kg}$ (control and CMS model groups); Rhodiola 250 $\mathrm{mg} / \mathrm{kg}$; Rhodiola $500 \mathrm{mg} / \mathrm{kg}$; Curcuma 250 mg/kg; Curcuma $500 \mathrm{mg} / \mathrm{kg}$, Rhodiola $250 \mathrm{mg} / \mathrm{kg}$ and Curcuma $250 \mathrm{mg} / \mathrm{kg}$. All groups except the control were stressed daily according to a CMS protocol. Changes in glucose preference, weight gain and locomotor activity were recorded. In the sixth week the animals were challenged with LPS and rats' sera were obtained for ELISA evaluation of TNF-a and IL-6 levels.

Results: The animals from the model group decreased their weight gain, glucose preference and locomotor activity compared to controls. The groups exposed to stress and treated with Rhodiola $500 \mathrm{mg} / \mathrm{kg}$, Curcuma $500 \mathrm{mg} / \mathrm{kg}$ and their combination increased their locomotor activity compared to the model group. High expression of the pro-inflammatory cytokines TNF- $\alpha$ and IL- 6 were found in all groups exposed to CMS and challenged by LPS.

Conclusions: The groups exposed to the stress procedure showed a variety of depression-like behavioral changes. In addition, ELISA tests showed that CMS is affecting rats' immunity by increasing the cytokines' levels. These changes could be reversed by administration of Rhodiola and Curcuma in combination suggesting synergic interaction regarding their anti-inflammatory and anti-stress effects.

\section{BACKGROUND}

Depression is the second most prevalent cause of disability and decreased quality of life. The World Health Organization (WHO) defines depression as a common mental disorder, characterized by sadness, loss of interest or pleasure (anhedonia), feelings of guilt or low self-esteem, disturbed sleep or appetite, feelings of tiredness and poor concentration.
The nature of depression is still inadequately explained, even with current dominant theories of serotonergic dysfunctions and the excessive secretion of cortisol. Less than $40 \%$ of depressed patients achieve remission with the currently available antidepressants, which mainly target serotonin. ${ }^{1}$ Recent studies have suggested increased levels of pro-inflammatory cytokines in depression. ${ }^{2,3}$ 
Stress is usually defined as a state of disturbed homeostasis inducing somatic and mental adaptive reactions, globally defined as 'stress response', aiming to reconstitute the initial homeostasis or a new level of homeostasis after successful adaptation, i.e., allostasis. ${ }^{4}$ There is wide consensus and support from preclinical and clinical data that stress exposure conceivably plays a causal role in the etiology of major depressive disorder (MDD) and depression-like disorders. ${ }^{5}$

The chronic mild stress (CMS) model was firstly introduced by Katz and colleagues in the early 1980s by using series of severe stressors on rats. Later it was modified by Willner by prolonging the time of the experiment as well as decreasing the severity of the stressors to trigger depressive-like state in rats. ${ }^{6,7}$ Today it is one of the most valid animal models to induce anhedonia-like behavior which is one of the core symptoms of depression. Typical changes in the animals subjected to the CMS model are decrease in intake and preference of sweetened liquid (glucose/sucrose-water), changes in weight gain, and increase in immobility which can be observed in forced swim test or an open-field test.

Even though the exact pathophysiology of depression is not fully revealed it is known that stressful experiences have impact on the development of the depression in humans. There is a great deal of correlation evidence that patients who suffer from depression have elevations in circulating cytokines that are pro-inflammatory in nature such as TNF- $\alpha$, IL-1 $\beta$, IL- $6 .{ }^{2}$ Developments in the field of psychoneuroimmunology have demonstrated that major depressive disorder may be associated with a disturbance of immune functions. ${ }^{8,9}$

Like cytokines, the bacterial endotoxin, lipopolysaccharide (LPS), is a potent hippothalamo-pituaryadrenal (HPA) activator, and elicits marked sickness behavior. ${ }^{10-12}$ When LPS is systemically administered, activation of Toll-like receptor-4 (TLR-4) on immune cells occurs, provoking the release of IL-1 $\beta$ along with a cascade of other cytokines, such as IL- 6 and TNF- $\alpha .{ }^{13}$ These cytokines are thought to influence central neuronal processes, thus promoting behavioral changes.

Rhodiola rosea L. (family Crassulaceae) is a traditional medicinal plant known to stimulate the nervous system, to decrease depression, to enhance work performance, and to reduce fatigue and symptoms of asthenia subsequent to intense physical and psychological stress. ${ }^{14,15}$ Therefore, due to its ability to increase the resistance of an organism to environmental stress factors and to avoid damage from such factors, Rhodiola has been defined as an 'adaptogen'. ${ }^{16,17}$

Curcuma longa L. (family Zingiberaceae) known as turmeric possesses wide range of beneficial effects including anti-inflammatory and neuroprotective. ${ }^{18}$ The extracts of Curcuma has been shown to have a powerful antioxidant, anti-inflammatory, lipid reducing, immunomodulatory and sedative actions. ${ }^{19,20}$

\section{AIM}

The main aim of the present study was to evaluate the effect of chronic treatment with extracts from Rhodiola rosea L. and Curcuma longa L. on immunoreactivity of animals subjected to a chronic mild stress model followed by LPS-induced inflammation model.

\section{MATERIALS AND METHODS}

\section{Materials}

The studied extracts were commercially available. Standardized Rhodiola rosea L. extract of Nature's Way Products LLC (Green Bay, USA) and standardized Curcuma longa L. extract of Fact Products Inc (Salt Lake City, USA) were purchased from a local pharmacy store in Plovdiv, Bulgaria. The phytochemical profile of the extract was evaluated by means of nuclear magnetic resonance (NMR) spectroscopy. The sample preparation for NMR analyses was performed according to recently described protocol by Georgiev et al..$^{21,22}$

\section{Animals}

Fifty-six male Wistar rats with initial body weight ranging from $190 \mathrm{~g}$ to $230 \mathrm{~g}$ were provided by the Plovdiv Medical University Animal Facility (Medical University of Plovdiv, Bulgaria). They were randomized into 7 groups with 8 animals each. Rats were housed in standard laboratory conditions $\left(23-25^{\circ} \mathrm{C}\right.$, $50-55 \%$ humidity, 12/12-h light/dark cycle) and were provided with food and water ad libitum.

All experiments were carried out according to the guidelines for using laboratory animals in the EU European community guidelines/ EEC Directive of 1986. Permission for the study was obtained by the Bulgarian Food Safety Agency № 98/22.05.2014 and from the Ethic Committee of the Medical University Plovdiv № 2752/09.11.2015.

\section{TREATMENT REGIMEN}

The animals were treated orally daily during the six weeks of the study with: distillated water $10 \mathrm{ml} / \mathrm{kg}$ 
(control group and CMS model group); Rhodiola $250 \mathrm{mg} / \mathrm{kg}$; Rhodiola $500 \mathrm{mg} / \mathrm{kg}$; Curcuma 250 $\mathrm{mg} / \mathrm{kg}$; Curcuma $500 \mathrm{mg} / \mathrm{kg}$, Rhodiola $250 \mathrm{mg} / \mathrm{kg}$ and Curcuma $250 \mathrm{mg} / \mathrm{kg}$. A stainless steel gavage needle with ball tip was used for the intragastric administration with a volume of $10 \mathrm{ml} / \mathrm{kg}$ body weight. Animals in the control and the CMS model groups were treated with distilled water in the same volume as a vehicle. The herbal extracts were dissolved in distilled water prior to administration.

\section{STUdY DESIGN}

All groups except the controls were stressed according to a modified chronic mild stress (CMS) procedure lasting 4 weeks. . $^{67,12,14,20}$ The following stressors were introduced daily in a random manner to avoid habituation: reversed light/dark cycle, nipped tails, food deprivation, water deprivation, tilted cage, wet cage bedding, and loud noise. The control group was kept under standard laboratory conditions in separate room without any contact with the stressed animals.

Body weight of the animals was measured on Mondays every week for calculation of body weight gain averages during the CMS period.

Glucose preference test involved a 24-h food and/ or water deprivation, followed by offering of two bottles one with $2 \%$ glucose solution and one with water. ${ }^{7}$ The animals were tested at the start of the experiment to record the baseline preference of the sweetened solution over water. The glucose preference tests trials were performed every Monday in order to use the food/water deprivation stressors in the CMS protocol as stimulation for the test. Intake was measured by weighing the two pre-weighed bottles at the end of the test. Glucose preference was calculated as a percentage of the volume of glucose intake over the total volume of fluid intake.

On the first day after the CMS protocol the spontaneous exploratory behaviour was measured in the open-field test, which was performed with minor modification from that described in the literature. ${ }^{23}$ Automatic activity cage apparatus (Ugo Basile, Italy) with infrared detectors was used. Rats were placed individually in the centre of the open field to explore freely for a 5-min session. The horizontal locomotor activity and vertical activity were recorded. The apparatus was cleaned with detergent prior to each test session to remove any olfactory cues.

On the first day of the sixth week the animals were challenged with lipopolysaccharide (LPS) to test their immune reactivity. LPS from Escherichia coli (serotype 055:B5) was purchased from SigmaAldrich Chemie GmbH (Steinheim, Germany) and dissolved in sterile normal saline and was injected intraperitoneally in a dose of $250 \mu \mathrm{g} / \mathrm{kg}$. Four hours after the LPS administration blood samples were collected for estimation of the concentration of TNF- $\alpha$ and IL- 6 in serum.

\section{SERUM SAMPLE PREPARATION}

Blood sample was obtained from the tail vein, clotting for $60 \mathrm{~min}$ at room temperature and then centrifuged ( $\left.3000 \mathrm{rpm}, 4^{\circ} \mathrm{C}, 10 \mathrm{~min}\right)$. The supernatant (i.e. serum sample) was subsequently achieved and stored at $-80^{\circ} \mathrm{C}$ until use.

\section{ELISA DETECTION OF CYTOKINES}

The concentrations of TNF- $\alpha$ and IL- 6 in serum were measured by specific enzyme-linked immunosorbent assay (ELISA). The tests were performed using the Rat IL-6 ELISA KIT of Diaclone SAS (Besancon Cedex, France) and Rat TNF- $\alpha$ ELISA KIT of Diaclone SAS (Besancon Cedex, France) strictly following the manufacturer's recommendations. The optical density was detected at $450 \mathrm{~nm}$ and reference filter at $620 \mathrm{~nm}$. Minimal detection levels were $19 \mathrm{pg} / \mathrm{ml}$ for IL-6 and $15 \mathrm{pg} / \mathrm{ml}$ for TNF- $\alpha$. Each sample concentration was calculated from the linear equation derived from the standard curve of the concentrations of the cytokine.

\section{Statistical anAlysis}

Data management was performed using MS Excel and SPSS 17.0 statistical software for Windows. All observed parameters were expressed as mean \pm standard error of the mean (SEM) for each group. The Kolmogorov-Smirnoff test was used as a normality test. Comparison between groups was carried out using one-way analysis of variance (ANOVA) for independent measures. Post hoc comparisons were carried out with Tukey HSD test. Comparison within groups was done using one-way analysis of variance (ANOVA) for repeated measures followed by Bonferroni post hoc test. A value of $\mathrm{P}<0.05$ was considered representative of a significant difference.

\section{RESULTS}

BeHAVIORAL TESTS.

Glucose preference test. There was no difference among the groups in the baseline levels of glucose intake. The control group decreased gradually their glucose preference from $100 \%$ to $63 \%$ over the six weeks of the study. Rats exposed to CMS showed 
sharper gradual decrease in glucose preference from $100 \%$ to around $30 \%$ until the fifth week of the study. The decrease in the glucose preference for the CMS groups was significantly stronger than in the controls from week 3 until the end of the study. From the fifth to sixth week the CMS model group showed slight increasing trend in their glucose preference. The group treated with Rhodiola $250 \mathrm{mg} / \mathrm{kg}$ showed significant increase in glucose preference compared to the CMS model group at weeks 5 and 6 . The group treated with Rhodiola $500 \mathrm{mg} / \mathrm{kg}$ showed increased preference compared to the model group only in week 6 of the study. The groups exposed to CMS and treated with Curcuma in both doses or the combination of the two extracts did not show significant difference in their glucose preference compared to the CMS model group (Fig. 1).

\section{BODY WEIGHT}

The control group increased their body weight significantly from the third week $(231 \mathrm{~g})$ till the end of the experiment (293 g) compared to the initial weight (202 g). Rats from the CMS model group did not change significantly in weight over the whole experimental period (in the range between $195 \mathrm{~g}$ and 219 g). The groups treated with Curcuma in both doses and the group treated with the combination from Rhodiola and Curcuma in $250 \mathrm{mg} / \mathrm{kg}$ showed increased weight (around $250 \mathrm{~g}$ in the sixth week) compared to the CMS model group from week 3 until the end of the study. However all groups subjected to the CMS protocol failed to gain weight to extend comparable to the non-stressed control regardless their treatment (Table 1).

\section{LOCOMOTOR ACTIVITY}

On the locomotor activity test the CMS model group showed significantly higher number of horizontal movements than the control group. Rats exposed to CMS and treated with the high dose of Rhodiola 500 $\mathrm{mg} / \mathrm{kg}$, Curcuma $500 \mathrm{mg} / \mathrm{kg}$ or the combination of them Rhodiola $250 \mathrm{mg} / \mathrm{kg}$ and Curcuma $250 \mathrm{mg} / \mathrm{kg}$ showed significantly higher numbers of horizontal movements compared to the CMS model group. We did not observe statistically significant difference in the vertical locomotor activity (Fig. 2).

\section{ELISA DETECTION OF CYTOKINES}

\section{TNF- $\alpha$ levels}

In the rats' sera from the group exposed to CMS and LPS combined the level of TNF- $\alpha$ was signifi- cantly higher compared to the control group and to the groups exposed to CMS or LPS alone. In the animals which were exposed solely to the LPS the level of TNF- $\alpha$ was significantly higher than the CMS-only exposed rats. The decrease in the level of the TNF- $\alpha$ was significant in the rats treated with Rhodiola $500 \mathrm{mg} / \mathrm{kg}$, Curcuma $250 \mathrm{mg} / \mathrm{kg}$ and in the rats which were treated with the combination of both extracts in comparison with the CMS and LPS combined model group (Fig. 3).

\section{IL-6 levels}

Significant difference between the IL-6 levels of the control group and the CMS or LPS exposed groups was observed. The group exposed to CMS and LPS combined showed significantly higher levels of IL-6 compared to the control group and to the groups exposed to CMS or LPS alone. All groups treated with Rhodiola, Curcuma and the combination of them showed significant increase in the level of IL-6 compared to the CMS and LPS combined model group independent from their dose (Fig. 4).

\section{DISCUSSION}

The present study aimed to evaluate the effect of chronically administered extracts from Rhodiola and Curcuma in CMS procedure followed by LPS challenge on the development of depression-like behavior in rats and their immunoreactivity. Both extract used are extensively studied as herbal medicines in the treatment of depression and stress-induced disorders. ${ }^{14,15,17-20,24}$ The novelty of the study is the evaluation of their efficacy in combination and testing possible synergic effects. In addition, data on the effect of these two plants on LPS-induced immunoreactivity in CMS was obtained.

Decrease in glucose preference test is representative for anhedonia, defined as a lack of interest in rewarding stimuli, which is the core symptom of depression and primary focus in CMS-induced depression model. ${ }^{6,7,11}$ Anhedonia with alterations in locomotor activity and drop of body weight gain reflect the depression-like state found in CMS-treated rats. The present study confirmed that the CMS protocol induce such depression-like symptoms in rats. Chronic treatment with extract of Rhodiola can increase the glucose intake of depressive rats, making them recover from the anhedonic state. These results are in line with previous studies which have found a beneficial effect of Rhodiola extract in CMS model. Chen et al. have suggested that Rhodiola improve the serotonin deficiency in 


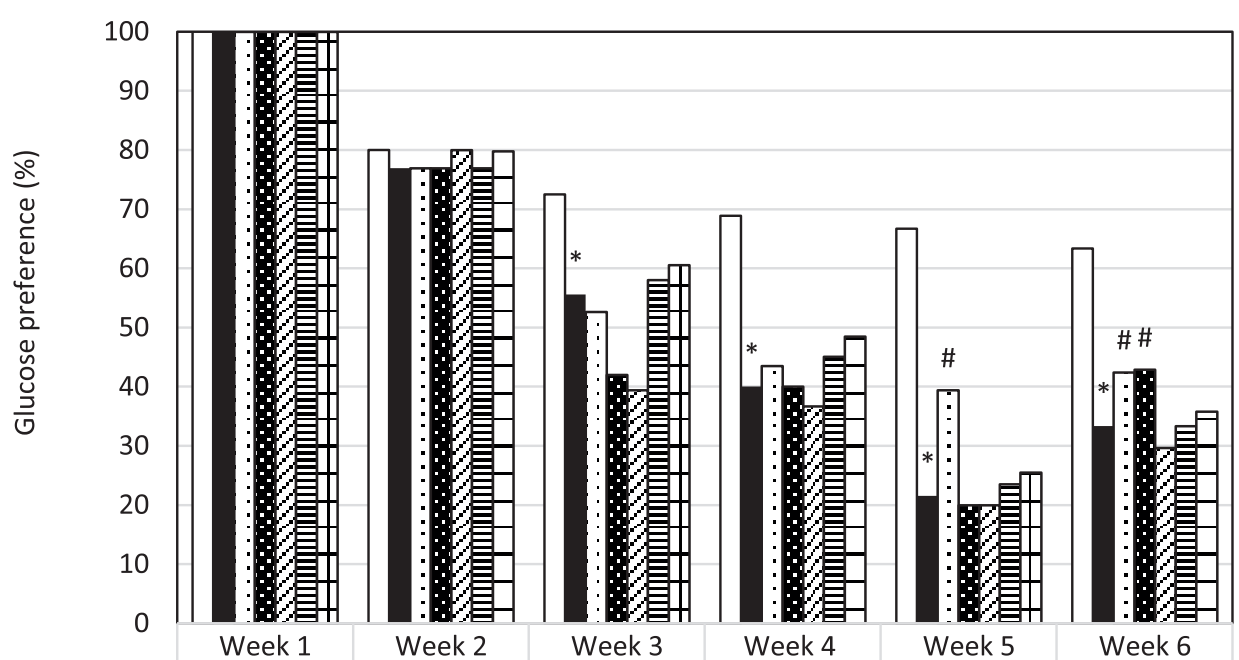

\begin{tabular}{|c|c|c|c|c|c|c|}
\hline$\square$ Controls & 100 & 80 & 73 & 69 & 67 & 63 \\
\hline - CMS & 100 & 77 & 56 & 40 & 22 & 33 \\
\hline 口CMS+Rhodiola $250 \mathrm{mg} / \mathrm{kg}$ & 100 & 77 & 53 & 43 & 39 & 42 \\
\hline CMS+Rhodiola $500 \mathrm{mg} / \mathrm{kg}$ & 100 & 77 & 42 & 40 & 20 & 43 \\
\hline$\triangle \mathrm{CMS}+$ Curcuma $250 \mathrm{mg} / \mathrm{kg}$ & 100 & 80 & 39 & 37 & 20 & 30 \\
\hline 目CMS+Curcuma $500 \mathrm{mg} / \mathrm{kg}$ & 100 & 77 & 58 & 45 & 24 & 33 \\
\hline $\begin{array}{c}\text { 巴CMS+Rhodiola } 250 \mathrm{mg} / \mathrm{kg}+\text { Curcuma } \\
250 \mathrm{mg} / \mathrm{kg}\end{array}$ & 100 & 80 & 61 & 49 & 25 & 36 \\
\hline
\end{tabular}

Figure 1. Glucose preference (\%) over the 6 weeks of study $\left({ }^{*} \mathrm{p}<0.05\right.$ compared to the same day control group; ${ }^{\#} \mathrm{p}<0.05$ compared to the same day CMS model group).

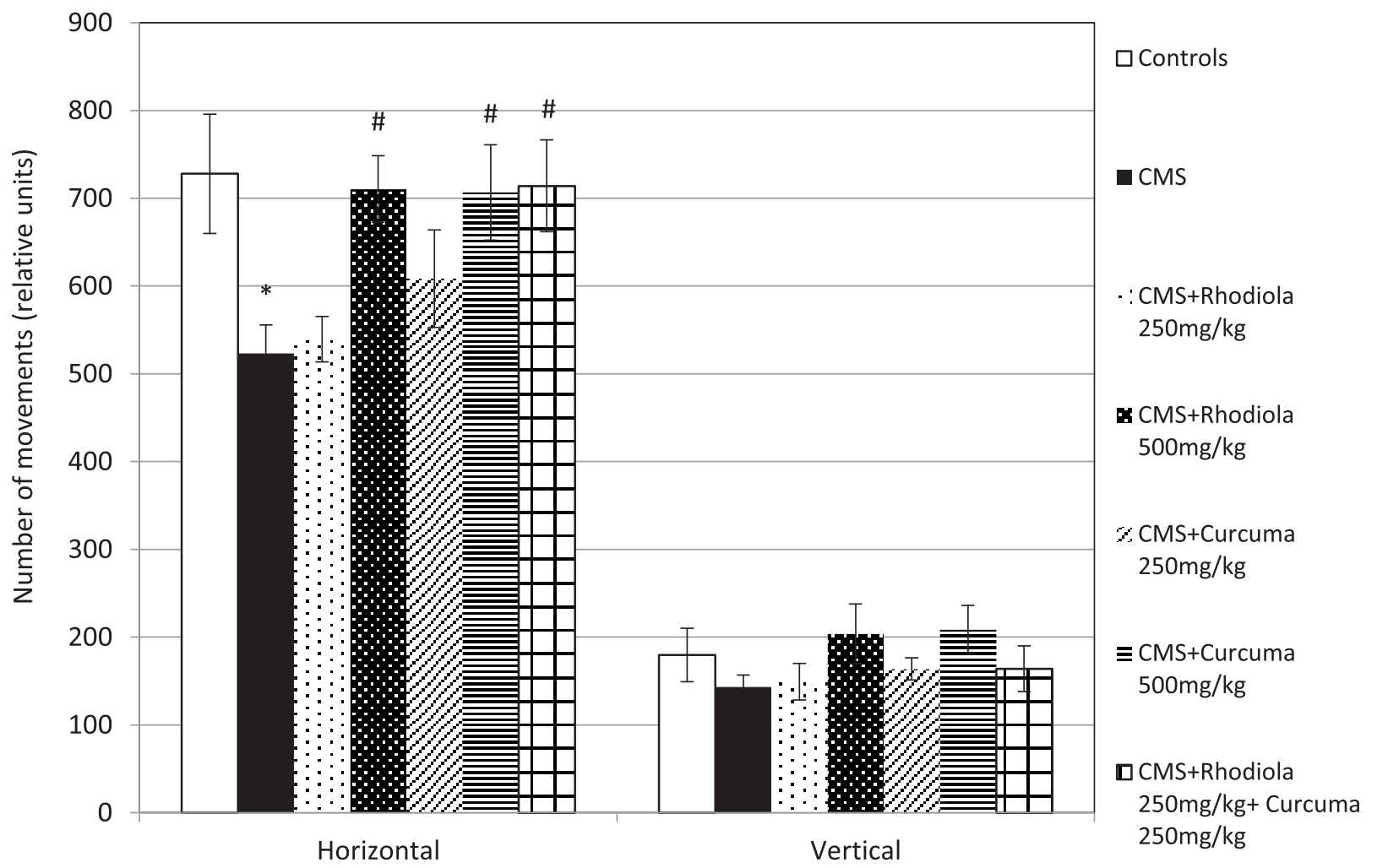

Figure 2. Locomotor activity test $\left({ }^{*} \mathrm{p}<0.05\right.$ compared to the control group; ${ }^{*} \mathrm{p}<0.05$ compared to the CMS model group). 


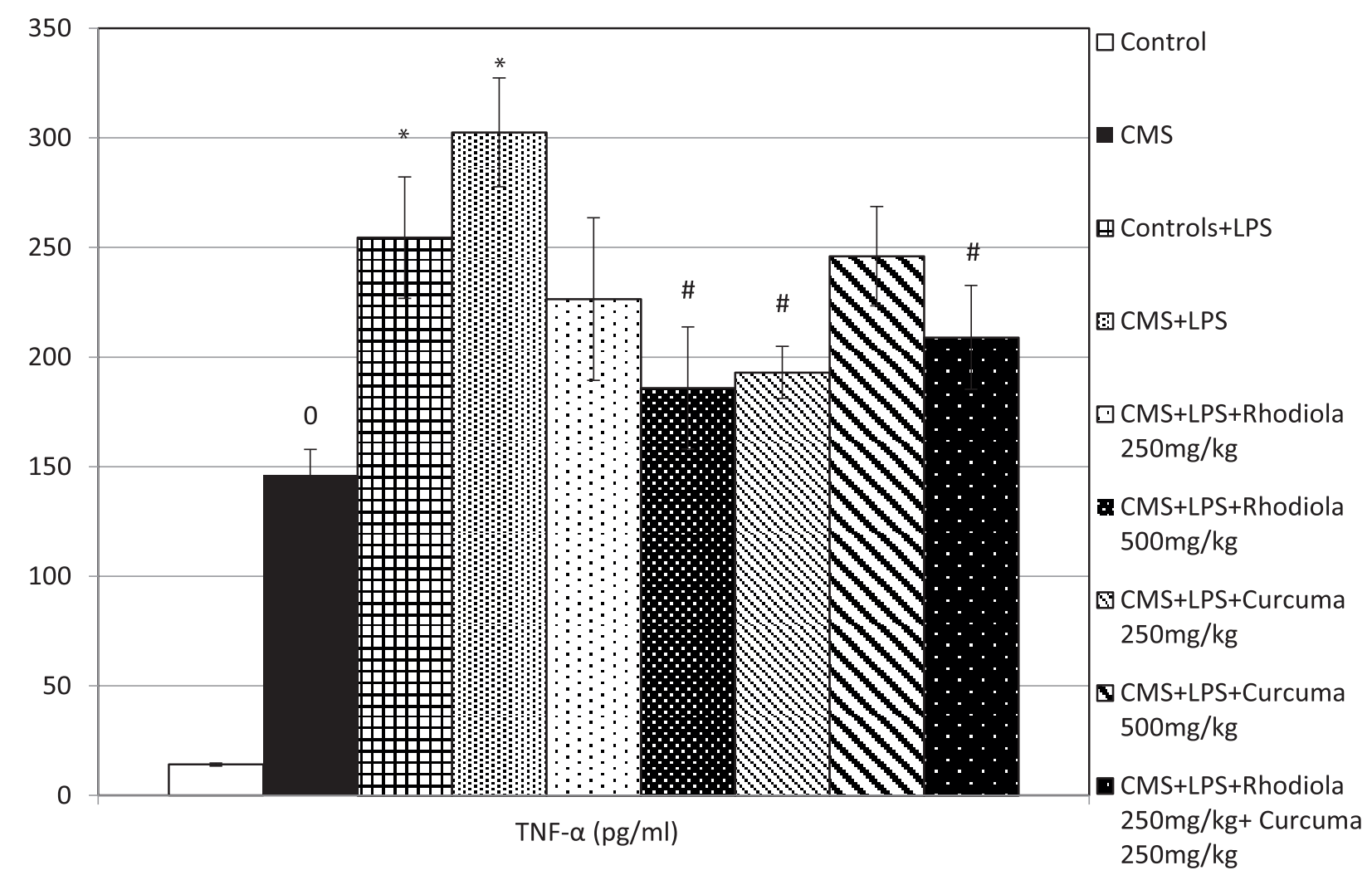

Figure 3. TNF- $\alpha$ levels in rats' sera in $\mathrm{pg} / \mathrm{ml}\left({ }^{0} \mathrm{p}<0.05 \mathrm{CMS}\right.$ model group compared to the control group; ${ }^{*} \mathrm{p}<0.05$ compared to the CMS model group; $\mathrm{p}<<0.05$ compared to the CMS+LPS group).

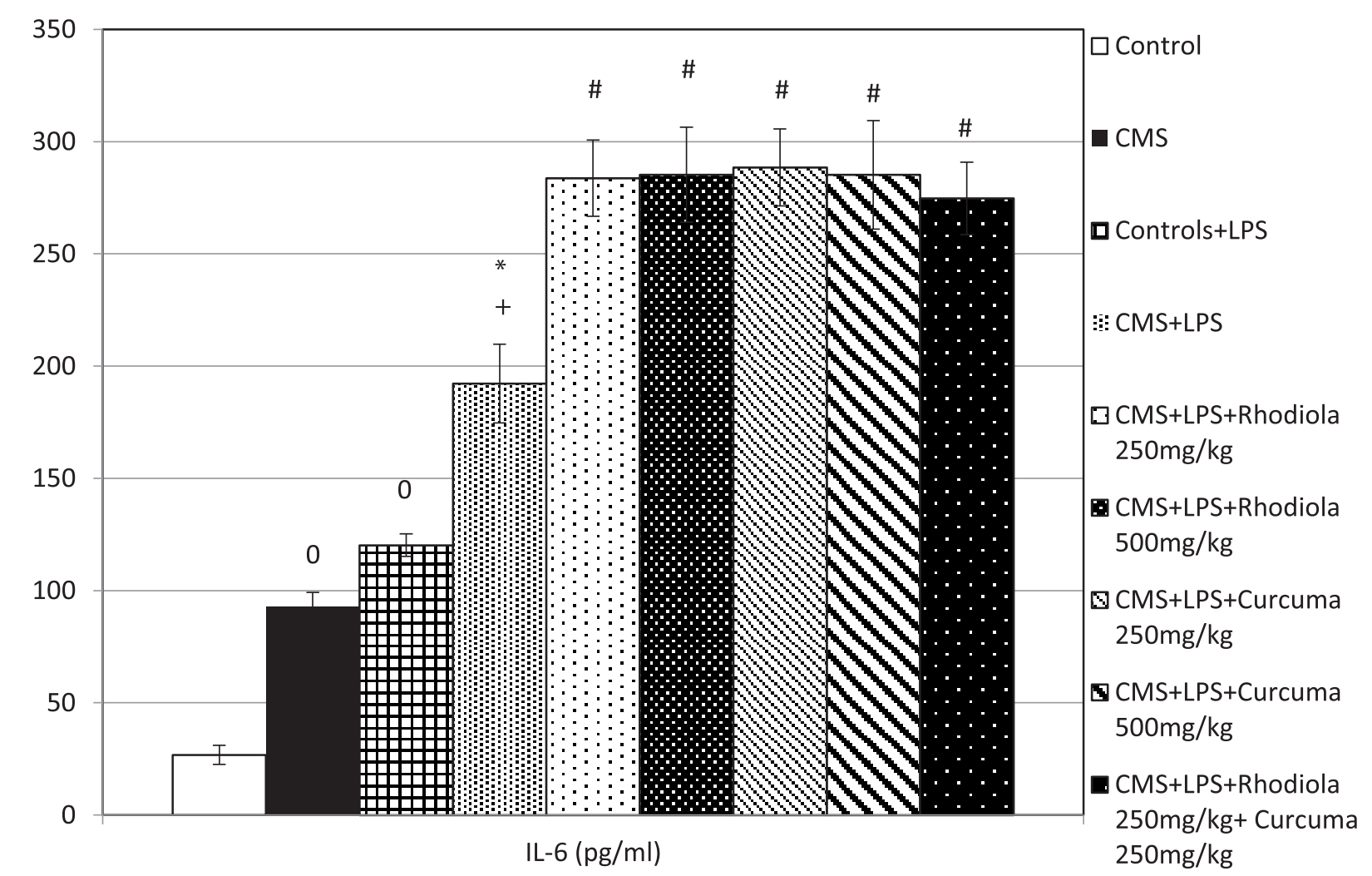

Figure 4. IL-6 levels in rats' sera in $\mathrm{pg} / \mathrm{ml}\left({ }^{0} \mathrm{p}<0.05 \mathrm{CMS}\right.$ model group compared to the control group; * $\mathrm{p}<0.05$ CMS+LPS group compared to the CMS model group; $+\mathrm{p}<0.05$ CMS + LPS group compared to the LPS model group; ${ }^{*} \mathrm{p}<0.05$ compared to the CMS+LPS group). 
Table 1. Body weight gain in grams over the six weeks of study

\begin{tabular}{|c|c|c|c|c|c|c|}
\hline & \multicolumn{6}{|c|}{ Body weight $(g)$ mean \pm SEM } \\
\hline & Week 1 & Week 2 & Week 3 & Week 4 & Week 5 & Week 6 \\
\hline Control group & $202.5 \pm 4.53$ & $195 \pm 2.67$ & $231.25 \pm 3.98^{0}$ & $247.5 \pm 4.12^{0}$ & $275 \pm 3.78^{0}$ & $293.75 \pm 2.63^{0}$ \\
\hline CMS model group & $210 \pm 4.23$ & $190 \pm 2.68$ & $193.75 \pm 3.24 *$ & $207.5 \pm 3.66^{*}$ & $208.75 \pm 3.50^{*}$ & $219.3 \pm 3.33^{*}$ \\
\hline $\begin{array}{l}\text { CMS + } \\
\text { Rhodiola } 250 \mathrm{mg} / \mathrm{kg}\end{array}$ & $201.25 \pm 4.79$ & $195 \pm 2.67$ & $206.25 \pm 1.82$ & $226.25 \pm 4.60$ & $223.75 \pm 2.63$ & $228.75 \pm 2.95$ \\
\hline $\begin{array}{l}\text { CMS + } \\
\text { Rhodiola } 500 \mathrm{mg} / \mathrm{kg}\end{array}$ & $198.75 \pm 2.67$ & $188.75 \pm 5.15$ & $197.5 \pm 4.90$ & $226.25 \pm 8.00$ & $221.25 \pm 6.39$ & $226.875 \pm 7.19$ \\
\hline $\begin{array}{l}\mathrm{CMS}+ \\
\text { Curcuma } 250 \mathrm{mg} / \mathrm{kg}\end{array}$ & $198.75 \pm 2.27$ & $211.25 \pm 3.98$ & $240 \pm 5.35^{\#}$ & $238.75 \pm 6.39^{\#}$ & $247.5 \pm 5.42^{\#}$ & $250 \pm 5.17^{\#}$ \\
\hline $\begin{array}{l}\text { CMS + } \\
\text { Curcuma } 500 \mathrm{mg} / \mathrm{kg}\end{array}$ & $207.5 \pm 4.11$ & $206.25 \pm 2.63$ & $227.5 \pm 3.14^{\#}$ & $232.5 \pm 3.15$ & $240 \pm 3.89^{\#}$ & $245 \pm 5.00^{\#}$ \\
\hline $\begin{array}{l}\mathrm{CMS}+\text { Rhodiola } 250 \mathrm{mg} / \\
\mathrm{kg}+\text { Curcuma } 250 \mathrm{mg} / \mathrm{kg}\end{array}$ & $200 \pm 1.89$ & $195 \pm 3.78$ & $227.5 \pm 4.53^{\#}$ & $227.5 \pm 5.90$ & $237.5 \pm 6.41^{\#}$ & $241.875 \pm 6.47^{\#}$ \\
\hline
\end{tabular}

${ }^{0} \mathrm{p}<0.05$ compared to first day control group; ${ }^{*} \mathrm{p}<0.05$ model group compared to same day control group; ${ }^{*} \mathrm{p}<0.05$ compared to the CMS model group.

hippocampus of depressive rats and also restores the quantity of proliferative cells in dentate gyrus. ${ }^{24}$ Mattioli et al. showed that chronic administration of extract of Rhodiola results in potent inhibition of the behavioral and physiological changes induced by CMS to extent comparable with the selectiveserotonin reuptake inhibitor fluoxetine. ${ }^{14}$ In the present study, all the other experimental groups treated with Curcuma in both doses and Rhodiola and Curcuma in combination failed to reverse the changes in glucose preference induced by the CMS procedure.

The effect of CMS on body weight is controversial. One serious criticism about the CMS induced loss of body weight was correlation of it with the decreasing trend on the intake of sweet solutions observed in CMS exposed rats. However, a large number of studies have now demonstrated that CMS-induced decrease in glucose/sucrose intake, as well as the reversal of those effect by antidepressant drugs, are independent of changes in body weight. ${ }^{25}$ In the present study, all groups subjected to the CMS protocol failed to gain weight in a manner comparable to the non-stressed animals. However, during the last two weeks the animals treated with Curcuma in both doses and the combination of the two plants showed significant increase in their weight compared to the CMS model group. These results are in contrast with the trend in the result from the glucose preference test and confirm the aforementioned statement that the changes in these two parameters of the CMS paradigm are independent. The data found in the literature that Curcuma longa L. and its active component curcumin have antidepressant, anti-inflammatory and strong antioxidant properties supports our findings that chronic administration of extract of Curcuma could be beneficial in weight loss induced by chronic stress. ${ }^{18,20}$ Moreover, possible synergic effect of Rhodiola and Curcuma was observed regarding the normalization in body weight gain as an aspect from the depressive-like symptoms of the CMS model.

An open-field test consists of exposing an animal to an open arena, a new environment without any clearly aversive or appetitive stimuli, and let it explore it freely for a fixed amount of time. In this sense, it is the classical non-aversive and nonassociative task. The number of vertical movements (rearings) are innate exploratory postures of small rodents, and the newer the environment, the more rearings the animal will exhibit. The number of horizontal movements (crossings) also express exploration and have the advantage of measuring basal motor activity. The initial activity of a rat placed in novel surroundings (i.e., open field activity) has been taken as an indicator of its emotional state. Katz et al. investigated the effects of immediately antecedent stress upon open field activity in comparison with basal (i.e., unstressed) activity, and additionally, the effects of a history of chronic stress upon the above behavioral patterns. Acute exposure to a non-traumatic, non-debilitating stress (noise and light) consistently increased activity in comparison with basal activity. A history of chronic stress on 
the other hand reduced basal activity from control levels, and eliminated the activation response to acute stress. ${ }^{23}$ The study findings in the open-field test also showed decrease in horizontal locomotor activity induced by the CMS exposure. The tested extracts were able to reverse these changes with the high doses from Rhodiola $500 \mathrm{mg} / \mathrm{kg}$, Curcuma $500 \mathrm{mg} / \mathrm{kg}$ and the combination of both extracts. Rhodiola have been reported to influence the levels and activities of biogenic monoamines, not only serotonin, but also dopamine and norepinephrine, in the cerebral cortex, brain stem and hypothalamus due to inhibition of the activities of the enzymes responsible for monoamine degradation (monoamine oxidase and catechol-O-methyltransferase) and to facilitation of neurotransmitter transport within the brain. ${ }^{14,15,26}$ Therefore, we think that Rhodiola effectively increased horizontal locomotor activity by increasing norepinephrine. Another study using locomotor activity test showed that Rhodiola standardized extract stimulates the locomotor activity in rats, which also suggest stimulation of the CNS with possible involvement of the noradrenergic mechanisms. ${ }^{27}$ We have also observed increase in the horizontal locomotor activity within the animals treated with the combination of Rhodiola and Curcuma which indicates that they have a synergic effect on increasing the locomotor activity affected by the CMS procedure. However, we did not observe any significant effect in rats treated with the low doses of Rhodiola and Curcuma. In addition, no significant difference in the vertical activity was observed. Rearing behavior is known to be more sensitive to dopamine loss and should decline linearly as a function of dopamine levels. ${ }^{28}$ It could be speculated that in the present study neither the CMS procedure nor the two extracts used have affected the dopamine levels to that extend to cause a sharp vertical motor deficit.

Cytokines, the chemical messengers between immune cells, play crucial roles in mediating inflammatory and immune responses. Cytokines also mediate signaling between cells of non-immune tissues including the nervous system and play important role in both normal and pathology processes. ${ }^{2,3}$ According to their biological responses, cytokines are classified as pro- or anti-inflammatory, which can be cross-inhibitory. Pro-inflammatory and anti-inflammatory cytokines have different effects on brain development, neurogenesis, and synaptic plasticity. ${ }^{29}$

Activation of the inflammatory immune system has been implicated in the evolution of depressive- and anxiety-like states., ${ }^{2,29}$ In this regard, pro-inflammatory cytokines, such as interleukin- $1 \beta$ (IL-1 $\beta)$ or tumor necrosis factor alpha (TNF- $\alpha$ ), elicit behavioral, neuroendocrine and neurochemical responses reminiscent of those provoked by traditional stressors as well as those associated with major depressive illness. ${ }^{3,30}$ Cytokines could also play a role in promoting anhedonia, a key feature of depression.

In the present study elevation in the level of TNF- $\alpha$ after administration of LPS was observed. Acute activation of the peripheral or central innate immune system in laboratory animals, through the administration of LPS, induces depressive-like behavior. ${ }^{11-13}$ This data from the literature that LPS could induce depression-like changes in animals along with increase in the pro-inflammatory cytokines production similar to those when performing CMS procedure allows us to suggest that CMS model followed by an LPS-challenge would have even greater effect on the immunoreactivity in depressed rats. Elgartf et al. have reported that combined protocol of CMS and LPS repeated injection significantly increased TNF- $\alpha$ levels in comparison to groups exposed to CMS or LPS injection alone. ${ }^{12}$ In the study significant increase was also found for both TNF- $\alpha$ and IL- 6 in the group subjected to CMS and subsequently challenged by LPS in comparison with the groups exposed to either CMS or LPS alone. On the basis of the CMS and LPS combined model significant decrease was found in the levels of TNF- $\alpha$ in the groups chronically treated with Rhodiola, Curcuma and combination of both extracts. It is thought that Curcuma extract leads to decrease in the level of TNF- $\alpha$ based on the regulation of the abnormalities in the HPA-axis as well as its antiinflammatory properties - acting as COX-2 and NF-kB inhibitor. ${ }^{18-20,31}$ The influence of Rhodiola on the TNF- $\alpha$ levels could be explained with its strong antioxidant potential and anti-inflammatory effect. Lee et al. in their study observed decrease in the TNF- $\alpha$ levels after LPS challenge in mice treated orally with Rhodiola $500 \mathrm{mg} / \mathrm{kg}^{32}$

Significant increase in the serum IL-6 levels in rats exposed to the CMS procedure was observed. The administration of Curcuma and Rhodiola in different doses did not prevent the stress-induced increase in serum IL-6 levels, but even increased it. IL-6 is a cytokine produced by immune cells, astrocytes, microglia and neurons. ${ }^{33}$ It plays a key role in acute-phase protein synthesis, immune 
responses and inflammatory processes. IL-6 also shows a number of anti-inflammatory effects, such as induction of corticosteroid synthesis, and inhibition of IL- $1 \beta$ and TNF- $\alpha$ synthesis in vitro and in vivo. We were able to observe elevation in the level of IL- 6 by administration of LPS and by the CMS and LPS combined model. This data suggest that IL-6 has anti-inflammatory effects in the present study. It may be speculated that although Curcuma and Rhodiola suppress the IL-6 production by monocytes, they increase this production by lymphocytes. Kubera et al. in their study found that antidepressants (fluoxetine, imipramine, venlafaxine) are able to increase tryptophan level and serotonin metabolism in several brain regions by elevating IL-6 production in the periphery and the central nervous system and that the therapeutic activity of these drugs is at least partly connected with their effect on IL-6 production. ${ }^{34}$ Calapai et al. showed that IL-6 was necessary for the antidepressant action of Hypericum perforatum and that the activation of the central serotonergic metabolism following $H y$ pericum perforatum may be attributed to increased IL-6. ${ }^{35}$ Our data about the increased IL-6 level in all experimental groups treated with both extracts suggest similar mechanisms involved and could be interpreted as a manifestation of anti-depressant action. This idea is also supported when the results from the behavioral test and the cytokines evaluation are taken together.

\section{CONCLUSIONS}

The groups exposed to the CMS procedure for 4 weeks showed a variety of depression-like behavioral changes resembling anhedonia, including reduction in glucose preference, weight gain and locomotor activity compared to the non-stressed controls. These changes could be reversed by chronic administration of Rhodiola and Curcuma extracts. In addition, ELISA tests showed that CMS is affecting rats' immunity by increasing the levels of TNF- $\alpha$ and IL-6. Treatment with Rhodiola and Curcuma in combination can decrease the TNF- $\alpha$ levels suggesting synergic interaction of the two extracts regarding their immunomodulatory, anti-inflammatory and anti-stress effects. These results indicate that the combination of the two extracts may have therapeutic potential for treatment of stress-induced conditions and mild to moderate depression.

\section{ACKNOWLEDGEMENTS}

The authors declare that this work was financially supported by the Medical University of Plovdiv as part of project SDP15/2015 and project BG161PO003-1.2.03-0003-C0001.

\section{REFERENCES}

1. Krishnan V, Nestler EJ. Animal models of depression: molecular perspectives. Curr Top Behav Neurosci 2011;7:121-47.

2. Maes M. Depression is an inflammatory disease, but cell-mediated immune activation is the key component of depression. Prog Neuro-Psychopharmacology Biol Psychiatry 2011;35(3):664-75.

3. Raison CL, Capuron L, Miller AH. Cytokines sing the blues: Inflammation and the pathogenesis of depression. Trends Immunol 2006;27(1):24-31.

4. McEwen BS. Physiology and neurobiology of stress and adaptation: central role of the brain. Physiol Rev 2007;87(3):873-904.

5. Roozendaal B, McEwen BS, Chattarji S. Stress, memory and the amygdala. Nat Rev Neurosci 2009; 10:423-33.

6. Willner P. Validity, reliability and utility of the chronic mild stress model of depression: a 10-year review and evaluation. Psychopharmacology (Berl) 1997;134(4):319-29.

7. Willner P. Chronic mild stress (CMS) revisited: consistency and behavioural-neurobiological concordance in the effects of CMS. Neuropsychobiology 2005; 52(2):90-110.

8. Maes M, Mihaylova I, Kubera M, et al. Activation of cell-mediated immunity in depression: Association with inflammation, melancholia, clinical staging and the fatigue and somatic symptom cluster of depression. Prog Neuro-Psychopharmacology Biol Psychiatry 2012;36(1):169-75.

9. Kubera M, Basta-Kaim A, Papp M. The effect of chronic treatment with imipramine on the immunoreactivity of animals subjected to a chronic mild stress model of depression. Immunopharmacology 1995;30(3):225-30.

10. Kubera M, Curzytek K, Duda W, et al. A new animal model of (chronic) depression induced by repeated and intermittent lipopolysaccharide administration for 4 months. Brain Behav Immun 2013;31:96-104.

11. Gibb J, Hayley S, Gandhi R, et al. Synergistic and additive actions of a psychosocial stressor and endotoxin challenge: Circulating and brain cytokines, plasma corticosterone and behavioral changes in mice. Brain Behav Immun 2008;22:573-89.

12. Elgarf AS, Aboul-Fotouh S, Abd-Alkhalek HA, et al. Lipopolysaccharide repeated challenge followed by chronic mild stress protocol introduces a combined model of depression in rats: Reversibility by imipramine and pentoxifylline. Pharmacol Biochem 
Behav 2014;126:152-62.

13. Konsman JP, Veeneman J, Combe C, et al. Central nervous action of interleukin- 1 mediates activation of limbic structures and behavioural depression in response to peripheral administration of bacterial lipopolysaccharide. Eur J Neurosci 2008;28(12):2499-510.

14. Mattioli L, Funari C, Perfumi M. Effects of Rhodiola rosea L. extract on behavioural and physiological alterations induced by chronic mild stress in female rats. J Psychopharmacol 2009;23(2):130-42.

15. Panossian A, Nikoyan N, Ohanyan N, et al. Comparative study of Rhodiola preparations on behavioral despair of rats. Phytomedicine 2008;15(1-2):84-91.

16. Panossian A, Wikman G, Sarris J. Rosenroot (Rhodiola rosea): traditional use, chemical composition, pharmacology and clinical efficacy. Phytomedicine 2010;17(7):481-93.

17. Perfumi M, Mattioli L. Adaptogenic and central nervous system effects of single doses of $3 \%$ rosavin and $1 \%$ salidroside Rhodiola rosea L. extract in mice. Phytother Res 2007;21(1):37-43.

18. Tizabi Y, Hurley L, Qualls Z, et al. Relevance of the anti-inflammatory properties of curcumin in neurodegenerative diseases and depression. Molecules 2014;19:20864-79.

19. Kulkarni SK, Bhutani MK, Bishnoi M. Antidepressant activity of curcumin: involvement of serotonin and dopamine system. Psychopharmacology (Berl) 2008;201(3):435-42.

20. Xia X, Pan Y, Zhang W-Y, et al. Ethanolic extracts from Curcuma longa attenuates behavioral, immune, and neuroendocrine alterations in a rat chronic mild stress model. Biol Pharm Bull 2006;29(5):938-44.

21. Georgiev MI, Radziszewska A, Neumann M, et al. Metabolic alterations of Verbascum nigrum L. plants and SAArT transformed roots as revealed by NMRbased metabolomics. Plant Cell, Tissue Organ Cult 2015;123(2):349-56.

22. Vasileva LV, Getova DP, Doncheva ND, et al. Beneficial effect of commercial Rhodiola extract in rats with scopolamine-induced memory impairment on active avoidance. J Ethnopharmacol 2016;193:586-91.

23. Katz RJ, Roth KA, Carroll BJ. Acute and chronic stress effects on open field activity in the rat: Implications for a model of depression. Neurosci Biobehav
Rev 1981;5(2):247-51.

24. Chen Q-G, Zeng Y-S, Tang J-Y, et al. Effects of Rhodiola rosea on body weight and intake of sucrose and water in depressive rats induced by chronic mild stress. Zhong Xi Yi Jie He Xue Bao 2008;6(9):952-5.

25. Papp M, Gruca P, Lason-Tyburkiewicz M, et al. Antidepressant, anxiolytic and procognitive effects of rivastigmine and donepezil in the chronic mild stress model in rats. Psychopharmacology (Berl) 2016;233(7):1235-43.

26. van Diermen D, Marston A, Bravo J, et al. Monoamine oxidase inhibition by Rhodiola rosea L. roots. J Ethnopharmacol 2009;122:397-401.

27. Vasileva L, Getova D. Effects of Rhodiola rosea L. standardized extract on nociceptive reactions and locomotor activity. Trakia J Sci 2014;12:119-22.

28. Willard AM, Bouchard RS, Gittis AH. Differential degradation of motor deficits during gradual dopamine depletion with 6-hydroxydopamine in mice. Neuroscience 2015;301:254-67.

29. Deverman BE, Patterson PH. Cytokines and CNS development. Neuron 2009;64(1):61-78.

30. Hayley S, Poulter MO, Merali Z, et al. The pathogenesis of clinical depression: Stressor- and cytokineinduced alterations of neuroplasticity. Neuroscience 2005;135(3):659-78.

31. Zhao X, Wang C, Zhang J-F, et al. Chronic curcumin treatment normalizes depression-like behaviors in mice with mononeuropathy: involvement of supraspinal serotonergic system and GABAA receptor. Psychopharmacology (Berl) 2014;231(10):2171-87.

32. Lee Y, Jung J-C, Jang S, et al. Anti-inflammatory and neuroprotective effects of constituents isolated from Rhodiola rosea. Evid Based Complement Alternat Med 2013;e514049.

33. Barton BE. The biological effects of interleukin 6 . Med Res Rev 1996;16(1):87-109.

34. Kubera M, Grygier B, Wrona D, et al. Stimulatory effect of antidepressant drug pretreatment on progression of B16F10 melanoma in high-active male and female C57BL/6J mice. J Neuroimmunol 2011;240-241:34-44.

35. Calapai G, Crupi A, Firenzuoli F, et al. Interleukin-6 involvement in antidepressant action of Hypericum perforatum. Pharmacopsychiatry 2001;34(Suppl. 1): S8-10. 


\title{
Полезные эффекты долговременного лечения экстрактами Rhodiola rosea L. (золотого корня) и Curcuma longa L. (куркумы) на иммуно- реактивность животных, подвергнутых воздействию модели хрони- ческого мягкого стресса
}

\author{
Лилия В. Василева ${ }^{1,2}$, Кремена Е. Сарачева ${ }^{1,2}$, Мария В. Ивановска ${ }^{3,4}$, Атанаска П. Петро- \\ ва $^{3,4}$, Емир Сукоуглу ${ }^{5}$, Мариана А. Мурджева ${ }^{3,4}$, Дамянка П. Гетова-Спасова ${ }^{6}$ \\ ${ }^{1}$ Кафедра фармакологии и клинической фармакологии, Факультет медицины, Медицинский университет -Пловдив, Плов- \\ див, Болгария \\ 2 Кафедра фармакологии и лекарственной токсикологии, Факультет фармации, Медицинский университет- Пловдив, \\ Пловдив, Болгария \\ ${ }^{3}$ Кафедра микробиологии и иммунологии, Факультет фармации, Медицинский университет - Пловдив, Пловдив, Болгария \\ ${ }^{4}$ Секция иммунологической оценки посттравматического стрессового расстройства, Технологический центр неотложной \\ помощи (ТЦНП), Пловдив, Болгария \\ 5 Факультет медицины, Медицинский университет - Пловдив, Пловдив, Болгария \\ 6 Лаборатория экспериментальной нейрофармакологии, Технологический центр неотложной помощи (ТЦНП), Пловдив, \\ Болгария
}

\begin{abstract}
Адрес для корреспонденции: Лилия В. Василева, Кафедра фармакологии и клинической фармакологии, Факультет медицины, Медицинский университет -Пловдив, Пловдив, Болгария; Кафедра фармакологии и лекарственной токсикологии, Факультет фармации, Медицинский университет - Пловдив, бул. „Васил Априлов“ № 15A, 4002 Пловдив, Болгария

E-mail: vasileva.I.vl@gmail.com Тел: +359899514113
\end{abstract}

Дата получения: 23 июля 2016 Дата приемки: 08 марта 2017 Дата онлайн публикации: 09 мая 2017

Дата публикации: 22 декабря 2017

Ключевые слова: хронический мягкий стресс, иммунореактивность, воспаление, индуцированное LPS, Rhodiola, куркума

Образец цитирования: Vasileva LV, Saracheva KE, Ivanovska MV, Petrova AP, Sucouglu E, Murdjeva MA, Getova-Spasova DP. Beneficial effect of chronic treatment with extracts from Rhodiola rosea $\mathrm{L}$. and Curcuma longa L. on the immunoreactivity of animals subjected to a chronic mild stress model.

Folia Medica 2017;59(4):443-53. doi: 10.1515/folmed-2017-0046
Введение: Последние исследования устанавливают повышенные уровни противовоспалительных цитокинов при депрессии.

Цель: Целью настоящего исследования является установление эффекта экстрактов Rhodiola (золотого корня) и куркумы на иммунореактивность животных, подвергнутых воздействию модели хронического мягкого стресса (XMC) с последующим индуцированным липополисахаридом воспалением.

Методы: Мужским особям крыс Wistar $(n=56)$, которые были разделены на 7 групп, вводили перорально: дистиллированную воду 10 мл/кг (контрольная группа и группа, подвергнутая воздействию модели ХMC), Rhodiola 250 мг/ кг, Rhodiola 500 мг/кг, куркуму 250 мг/кг и куркуму 500 мг/кг. Все группы, за исключением контрольной, были подвергнуты ежедневному стрессогенному воздействию в соответствии с ХМС протоколом. Были установлены изменения во вкусовом предпочтении к глюкозе, увеличении веса и локомоторной активности. На шестой неделе эксперимента крысы были подвергнуты воздействию ЛПС и крысиная сыворотка была взята на обследование уровней TNF-a и IL-6 с применением ELISA.

Результаты: У животных, подвергнутых воздействию модели ХMC, установлено снижение веса, вкусового предпочтения к глюкозе, и локомоторной активности по сравнению с контрольной группой. В группах, подвергнутых стрессогенному воздействию и введению Rhodiola 500 мг/кг, куркумы 500 мг/ кг и их комбинаций, установлено повышение локомоторной активности по сравнению с модель группой. Высокая экспрессия противовоспалительных цитокинов TNF-a и IL-6 была установлена во всех группах, подвергнутых XMC и воздействию ЛПС.

Заключение: Группы, подвергнутые стрессу, показали разнообразие поведенческих изменений, сходных с изменениями при депрессии. В дополнение к тому, исследования с применением ELISA установили, что ХMC оказывает воздействие на иммунитет крыс повышением уровней цитокинов. Данные изменения могут быть контролированы применением Rhodiola и куркумы в комбинации, что в свою очередь наталкивает на мысль о синергетической реакции данных средств в отношении их противовоспалительных и антистрессовых свойств. 